\title{
Gendered educational trajectories and transnational marriage among West African students in France
}

\author{
Hélène Neveu Kringelbach
}

\begin{abstract}
French colonialism resulted in the inclusion of large numbers of West Africans into French educational institutions. Furthermore, the Senegambian region has a long history of inter-marriage with French citizens. This paper draws on this history to explore the interplay between migration, education and binational marriage over several generations of West African students, with a particular focus on Senegal. Students from Francophone countries continue to seek educational opportunities in France, but in recent years they have been increasingly affected by the tightening up of immigration policies. In this context, this paper suggests that marriage to a French spouse often plays an important role in the fulfilment of educational projects, and that this role is contingent on issues of gender and class. At times however, tensions between marriage in France and social expectations back home end up compromising education altogether.
\end{abstract}

Keywords: transnational marriage, Francophone West Africa, Senegal, international student mobility, citizenship, French immigration policy

In 2012-13, 12\% of the student population enrolled in higher education in France were international students (Campus France 2013). This placed France as the third country behind the US and the UK for its number of international students, with $7 \%$ of the total worldwide. There is indeed growing international mobility in the search for degrees, and the reproduction of elites is thus becoming globalized (Findlay et al. 2012). In the major receiving countries, universities are competing to attract international students, in large part for the financial contribution they make as state subsidies dwindle (King and Raghuram 2013). But students do not simply move to get degrees, and there is growing scholarly recognition that educational mobility is part of a broader life course. Yet, European states still treat international students as temporary guests, whose right to work or establish themselves should be curtailed. This is as much out of fear that they might swell the numbers of 'labour migrants' as out of concern for their education (Raghuram 2013). The role of states in encouraging or restricting access has been well documented, but so far the role of marriage to a citizen or resident in facilitating incorporation in receiving countries has received scant attention. Drawing on material collected for a study of transnational families between Senegal, France and the UK, this article seeks to address the gap in understanding the relationship between migration, transnational marriage and education. I take an anthropological perspective, thus keeping sight of life-course events and culturally constructed ideas on 'education'. I suggest that the role marriage plays in educational migration is not only contingent on immigration policies but also on issues of gender, class, and histories of migration.

New immigration policies curtailing the possibility for international students to acquire longer-term residency caused massive protest during Nicolas Sarkozy's presidential mandate. In May 2011, French Interior Minister Claude Guéant issued a memo instructing government agencies to limit the number of visa renewals for non-European Union (EU) students, and to curtail their right to work after graduating. Although these measures were abandoned by François Hollande's government in 2012, the status of international students in France remains fragile. In this context, marriage to a resident or citizen may play an important role in fulfilling educational projects by granting new rights, and eventually 
citizenship. This is the case in France, where spouse citizenship has historically been awarded fairly generously, albeit under conditions of 'integration' (Hajjat 2012). However, the passage to another life stage may also conflict with education.

This article focuses on Senegal since it was the first West African territory to be included into the French education system. As a result, Senegal has long provided the biggest contingent of Sub-Saharan African students in France. In 2012-13, they represented nearly 14\% of Sub-Saharan Africans enrolled in public or state-recognized institutions, or 8,995 individuals (Campus France 2013). This is a comparatively high figure in relation to Senegal's modest size, ${ }^{1}$ and to the documented Senegalese population in France: 98,527 in 2006 (Beauchemin, Caarls, and Mazzucato 2013).

This paper draws on approximately 9 months of fieldwork in France and 2 months in Senegal between 2011 and 2013. Research was conducted through semi-structured interviews, informal conversations and voluntary work with a French civic association providing legal advice to bi-national couples, Les Amoureux au Ban Public. The material was collected with family relationships and immigration issues in mind, and not with a focus on education. However, education often ranked high in people's aspirations. The study includes approximately 50 couples, 12 of whom are separated. There is an equal number of Francophone African men and women, and their French spouses. Two-thirds of the couples were recruited using the snowballing method, and the remainder through the 22 eveninglong legal advice sessions and social events I attended with the association in Paris. Individuals ranged in age from their twenties to their eighties. This is not a representative sample, and therefore the findings presented here cannot be generalized. My own identity as the child of a French mother and Senegalese father has facilitated access, but may also have skewed testimonies towards the more positive aspects of bi-national marriage. All informant names are pseudonyms.

\section{Conceptualizing student mobility, life-course and gender}

Following an enduring concern with the relationship between education and class, studies of spatial mobility and education have often focused on whether student mobility enabled individuals to achieve the upward mobility they sought (Waters 2006; Biao and Shen 2009; Rao 2010; Brooks and Waters 2011). Following the recent surge in international student mobility, however, a body of literature is emerging, which looks at students not simply as individuals engaged in the pursuit of degrees, but also as endowed with multiple identities (Waters 2006; Baas 2010). In this perspective, educational choices are part of broader aspirations, not simply to social mobility but also to achieving various individual, family- and class-based projects (Brooks and Everett 2008). Findlay et al. (2012), for example, found that the desire to qualify for long-term residency and citizenship was an explicit motivation for some British students in Australia, and Baas (2006) found that male Indian students in Australia considered marriage as an option to access permanent residency.

With a few exceptions (e.g. Olwig 2007; Valentin 2012), this literature rarely engages with the historical patterns of educational mobility induced by colonialism and other radical shifts. Historical studies on educational mobility in colonial empires have often focused on the political awakening of colonized youths in the metropolitan nations (Guimont 1997; Adi 1998; Dieng 2003; Vaillant 2006). On the whole however, these studies have not dealt with family relationships. In his work on (mainly male) African literati in France, Guèye $(2001,2002)$ mentions that many have married French women, but focuses on their political engagement. Though there is no space to do justice to the historical dimension of French-West African marriage here, I adopt a diachronic perspective to draw out the class-based, gendered and intergenerational aspects of the relationship between marriage and educational mobility in a post-colonial context.

\footnotetext{
${ }^{1}$ Senegal had an official population of 12.5 million in 2010 (ANSD 2011).
} 
This article also engages with the burgeoning literature on transnational marriage (e.g. Bryceson and Vuorela 2002; Constable 2005a; Cole 2010; Bloch 2011; Charsley 2012, 2013; Fernandez 2013). In recent years this work has shown how states have increasingly policed marriage across national boundaries in an effort to control human mobility. Scholars have also sought to disrupt popular ideas about the commodification of love and sex that is assumed to be at the heart of unions between individuals from wealthier and poorer countries, and this article also points to more nuanced interpretations of cross-border marriage. What does not often appear is that cross-border marriage can involve circulation in both directions. Much has been written on 'global hypergamy' (Constable 2005b), or women crossing regional or national boundaries to marry into wealthier localities or families. The Senegalese case, by contrast, involves both men and women 'marrying out'. As Constable (2005b, : 19) points out, 'hypergamy begs the question of how, for whom, and in what sense such marriages represent upward mobility'. In Senegal, marriage between African men and French women has become part of the kinship repertoire. Since the 1980s, the gender structure of 'mixed marriage' has shifted with a rise in the proportion of women among Senegalese migrants (Selly Baro 2005). Thus in 2011 in France, 321 Senegalese men married a French woman, while 202 Senegalese women married a French man (INSEE 2012). ${ }^{2}$ This does not include marriages celebrated in Senegal or elsewhere. To what extent and for whom, then, do French-West African marriages represent upward mobility?

Finally, the migration/education/marriage nexus begs the question of the relationship between spatial and social mobility. As established by geographers, and taken up by Olwig and Sørensen (2002), Valentin (2012) and others in the anthropological study of 'mobile livelihoods', social and spatial mobility are interrelated social processes. Spatial mobility, here, is conceived of as the capacity to travel freely through access to financial resources and visas. Social mobility should be understood as a combination of wealth, social status and lifestyle. Throughout West Africa, social mobility has been linked to travel and return with accumulated resources, often in the form of household dependents and the capacity to mobilize the labour of others; this is the notion of 'wealth in people' discussed in classical anthropological texts of the region (e.g. Meillassoux 1981). Men usually had the best access to mobility, while women often held ritual and spiritual power. However, in some parts of the region, such as the Casamance, the cash-cropping and waged labour introduced during the colonial period led unmarried women to travel seasonally for work and trade, and to accumulate household goods (Linares 1992; Lambert 2002). Social mobility through spatial mobility, therefore, has historically been gendered. If anything, the rise in migration to France through the $20^{\text {th }}$ century has reinforced the association between upward mobility and travel to return with increased resources. But downward mobility is always a risk, particularly since the high cost of travel means that those who migrate may have incurred debts. This was already the case in the $19^{\text {th }}$ and early $20^{\text {th }}$ centuries, when the mobility of the Soninke from the Senegal River Valley involved reciprocity among the more privileged groups (Manchuelle 1997). In the region, social mobility through travel is more likely to be achieved by those who already have resources in wealth and social capital ('people').

\section{Creole societies and educational mobility between West Africa and France}

From the $17^{\text {th }}$ century onwards, coastal Senegal has had a significant French presence, first via traders and later colonial administrators and army officers. A number of the early traders had relationships with African women. The Compagnie du Sénégal which employed them encouraged this since it improved their knowledge of the local languages, trading networks, and their survival rates (White 1999). Their creole descendants often held important positions in the transatlantic and regional trades,

\footnotetext{
${ }^{2}$ The category 'French' includes individuals of Senegalese origin who have acquired citizenship through a first marriage or long-term residency.
} 
and were among the first to attend the Catholic mission schools established from the $18^{\text {th }}$ century onwards. These early developments account for the comparative success of the Senegalese in French formal education. The first Black African representative at the French National Assembly, Blaise Diagne, was thus born on the creolized island of Gorée around 1872, and went to primary school in Saint-Louis before attending secondary school in France. In later generations, President Senghor and others joined the elite after following similarly mobile trajectories. Longer periods of study in France were usually preceded by regional mobility to attend French schools.

The colonial period also transformed notions of an 'educated person'. Ideas about educated persons, as the volume by Levinson et al. (1996) shows, are socially constructed. In the Senegambian region, ${ }^{3}$ the notion of a knowledgeable person had long been linked to hereditary status and to the successful completion of initiation cycles (Diop 1985). Islamic education also played an important role in the families of clerics in the pre-colonial period, and spread to all social categories during the $19^{\text {th }}$ century (Diouf 1990). By leading to posts in the colonial administration for those who held French degrees, colonial schooling heavily promoted formal education. After World War II, the need to reward the colonies for their participation in the war effort was recognized, and growing numbers of young Africans were awarded scholarships to study in France. From 2,000 students in 1949-50, the numbers grew to 8,000 in 1959, one-third of whom benefited from French studentships (Guimont 1997, : 7). But the studentships undermined the prestige of emerging African universities since French degrees became the reward for a faultless trajectory (Guèye 2002). Many among the post-war generations returned to their home countries to take up high-ranking positions in the late colonial administration, and after 1960 in the newly independent states. French colonialism, then, inscribed a durable connection between migration, foreign degrees and social mobility. In Senegal, this connection was reinforced in the 1980s, when a succession of student strikes in Dakar rendered the local university even less attractive (Guèye 2002). In contemporary Senegal therefore, an educated person is, to a large extent, a person with degrees, preferably from foreign institutions.

In the 1950s, African students in Paris socialized around the Latin Quarter, where they went to cafés and evening dances with French women, many of them from provincial towns. Several women I interviewed had fond memories of these impeccably turned out Black men who spoke of revolutionizing their home countries. They wore suits to distinguish themselves from migrant 'workers', and to fend off an ever-present racism. As some of the women confessed, meeting educated men from faraway countries was all the more exciting as they themselves were regarded as 'migrants' from smaller French towns. This colonial context helps to explain the historical propensity of Francophone African students, especially Senegalese, to marry French women. Two additional factors played into this: the difficulties African students faced in securing accommodation, and the scarcity of studentships. Indeed in the 1950s, in a context of militant anti-colonialism, the French state withdrew the scholarships of those African students deemed too militant or too fickle in their choice of a subject (Dieng 2003). After the independences in 1960, studentships became a strategic instrument in France's relations with its former colonies. Since Senegal and Côte d'Ivoire remained France's closest allies in West Africa, students from these countries enjoyed a comparatively favourable treatment. Nevertheless, by the mid-1970s studentships had become scarcer, and living conditions in France had deteriorated. Indeed, racial discrimination meant that African students faced huge difficulties in securing housing, an enduring problem to this day (Coulon and Paivandi 2003).

\section{Dual citizenship and social mobility in the post-independence years}

\footnotetext{
${ }^{3}$ The Senegambian region includes Senegal, the Gambia, and the border regions in Mauritania, Mali, Guinea Bissau and Guinea.
} 
In this context, marriage to French women often enabled university education to be completed in better conditions. One must be careful, however, not to reduce these relationships to instrumental arrangements, as evident in the substantial number of relationships of more than 10 years which I have come across. Here I focus on the generations who came of age between the 1950s and the 1970s.

For Senegalese students, there was an aura of elitism in bi-national marriage, even though not every Senegalese shared this view. Indeed several informants from different generations reported being warned before departure: 'Come back with degrees, not with a French woman!' Some of the reluctance expressed had to do with the fear of 'losing a child to France', especially in families where individuals from earlier generations had married in France and never returned. For those who could not claim French citizenship at independence or who chose not to, marriage later offered an alternative, and several of my older informants became French through marriage. They have remained dual nationals, and have often enjoyed better professional opportunities than their peers. As visas became required from the 1970s onwards, they also had the advantage of a greater spatial mobility, which contributed to their social mobility. The father of one of my informants is thus a Senegalese civil servant who married a French woman while a student in France in the 1970s. He acquired French citizenship through marriage, and kept his Senegalese citizenship alongside. His wife completed her studies and then worked to support the family, enabling him to do further graduate work. They eventually divorced and he remarried a Senegalese woman, who in turn acquired French citizenship by marrying him. He enjoyed a long career as a French diplomat before drawing on his dual nationality to return to Senegal and take part in Macky Sall's new government in 2012. Marriage greatly facilitated his education and his subsequent high-profile career.

Marriage into French families also enabled these individuals to learn about French cultural practices first-hand. Although intermarriage between citizens and immigrants does not always foster social incorporation (cf. Song 2009), there has long been a strong perception, in France, that the two were connected. ${ }^{4}$ Findlay et al. (2012: 128) rightly point out that international student mobility is not only about gaining formal knowledge, but 'also about other socially and culturally constructed knowledges'. How this happens in everyday life, however, is rarely described in the literature on student mobility. Yet the cultural knowledge acquired from spending time with French in-laws came to the fore in my informants' testimonies, across all generations. For Senegalese individuals, incorporation into a new social context is often understood within a model of tutor-guest relationship, which involves the initial protection of someone in whose household one may live for as long as it takes to establish oneself. In return, 'guests' remain indebted to their tutors once they have established their own household. Though this is obviously an ideal that is not always practised, it did affect the expectations young Senegalese had when marrying into French families.

Sadly however, rejection by French families was quite common. African students in France often came from middle class backgrounds, and it was particularly painful to be rejected by in-laws they regarded as no superior to their own relatives. In practice, families on both sides were often divided, with some members looking favourably upon the unions, and others showing hostility, even racism. For West African Muslims, religious difference was an additional issue. Indeed in some French Catholic families, the spouse's parents had looked forward to church weddings and Catholic grandchildren. But family relationships often improved if the African spouse was successful professionally. A couple who met in the early 1960s thus explained how the parents of the French wife, Jacqueline, went from complete rejection of the Senegalese (Muslim) husband, Seydou, to warming up to him. They showed this by way of small everyday gestures, such as refraining to serve pork in his

\footnotetext{
${ }^{4}$ For scholarly takes on whether the high percentage of 'mixed' marriages in France is indicative of the social incorporation of immigrants, see Collet (1993), Safi (2008), Tribalat (2009). See also Todd (1994), Alba and Nee (2005), Song (2009) and Rodríguez-García (2012) for broader discussions of the relationship between intermarriage and 'integration'.
} 
presence. Things had not started well however: during her first pregnancy, Jacqueline had 'fled' to Senegal and waited there for Seydou to finish his studies before taking up a post in a state-owned company. Jacqueline's father was a doctor, and given his hostility to this match, she had feared that he might 'interfere with the pregnancy', as she put it. If transnational marriage facilitated educational projects, individuals often felt that this came at a high personal cost.

In the Senegalese case, until the late 1970s many students returned home, where there was plenty of work for young men with French degrees. Several informants explained that a European wife was the ultimate validation of upward mobility. Some of the White French men who held technical and managerial posts in the Senegalese state sector, however, resented young men like Seydou, who not competed with them professionally, but also had French wives from 'good' families. These tensions were compounded by the fact that those Senegalese men who had neither foreign degree nor European wife resented the favourable treatment given to their peers.

\section{Forced immobility and the emergence of women migrants}

Since the mid-1970s, French immigration rules have been gradually tightened. Between 2003 and 2011, a succession of laws restricted access for non-EU citizens even further. If anything, this is likely to have made marriage to French citizens even more attractive.

Few students follow a straightforward path in any case, but the trajectories of Francophone African students are further complicated by the fact that they often discover new subjects once in France. Also, a number of informants found that some of the subjects which had appeared promising at home were far less prestigious globally, and had taken new orientations subsequently. But in the past decade, student visas have come under increasing scrutiny, and those who change courses or do not progress fast enough face deportation when their applications for visa renewals are rejected. Indeed, changing course of study places individuals under strong suspicion of being economic migrants posing as international students. In addition, a high proportion of international students face serious financial difficulties (Paivandi 1998). In this context, marriage may help to resume an educational project postponed due to a lack of legal status.

Michelle, a young woman from Gabon, thus told me how she had come to France to study French literature. After a couple of years, she no longer saw much promise in the subject, and enrolled in a more applied subject. Michelle was unable to renew her student visa because her trajectory was deemed 'inconsistent' by the local Préfecture. She then made ends meet by working in restaurant kitchens at night. But the despair of seeing her education thus compromised led her into depression, which she described as a deep feeling of apathy. She avoided public places and did not feel able to socialize: 'When I lost my papers, I switched myself off from society', she said. She eventually met a young French student with whom she fell in love. They decided to get married, but given her undocumented status, there was immediate suspicion that this might be a 'sham' marriage. The local town hall threatened to report them to the Chief Prosecutor, who might then have requested a police enquiry into their relationship. They eventually got married in the rural locality of her husband's parents, where the mayor was a friend. Michelle subsequently returned to Gabon to apply for a spouse visa from there. Her visa was granted, and she is now considering embarking on a new degree. In retrospect, she does not regret working in restaurant kitchens because she discovered France's 'hidden side' of invisible immigrants. She will apply for French citizenship after the four years of marriage required by French law.

So far, I have only touched on situations in which African students had met their spouse in France. But marriage to a European national encountered at home may also enable individuals to pursue studies in Europe. I use the term 'Europe' here because there is now a much greater diversity of origin countries in bi-national marriage with Francophone Africans, as evident in Rodríguez García's (2006) illuminating study of Senegalese-Spanish couples in Spain. For obvious language and historical 
reasons, Francophone African students still come to France in large numbers. But studentships and visas are scarce resources, and marriage may thus offer educational opportunities that would not exist otherwise. In Senegal this is particularly relevant for young women, who were often, until recently, marginalized in family decisions regarding which children would be schooled. Since the 1980s, access to education has become more balanced, but there remains a gap: in $2011,45 \%$ of boys of secondary school age were enrolled, against $37 \%$ of girls; the gap remained in higher education, with $10 \%$ and $6 \%$, respectively (UNESCO 2013). For young Senegalese women then, marrying 'out' may be an even more decisive element in pursuing higher education than it is for young men.

In the cases I have encountered where couples had met in Senegal, further education did not necessarily form part of the couple's plans at the time of marriage. But as some later moved to France or elsewhere, and faced difficulties in finding employment, they decided that further education for the Senegalese spouse would be beneficial. This is the case of Pierre and Aïda, who met in Senegal when Pierre was employed in the development sector. Aïda was completing a Bachelor's degree in Dakar, and had failed to get a studentship to study in France. They lived in Senegal for a few years before moving to France when Pierre's contract ended. He found employment first, and despite her Senegalese degree, Aïda found it difficult to get qualified jobs. The couple decided that a French degree would give her a better chance, even though there was now a young child, and living on a single salary was a challenge. Aïda embarked on a Masters' course in an applied subject. In the meantime she had acquired French citizenship, and she now qualified for exams to join the civil service. She has now been working as a civil servant for several years. Although she feels overqualified for her post, she is grateful for the relative job security citizenship has enabled her to achieve.

I have suggested that for Francophone African students in France, marriage may offer an alternative way of securing educational projects by enabling individuals to live in decent conditions, to avoid the grinding renewal of student visas, and eventually to become French citizens. This, as noted, does not imply that marriage is purely instrumental in such cases, although instrumental reasons are as likely to exist there as in any other marriage. Here it is worth mentioning the presence of a substantial amount of sex tourism in Senegal and the Gambia, which involves both sexes (Ebron 1997; Fouquet 2007; Salomon 2009). Some of these relationships lead to marriage migration, and an unknown proportion of the Senegambian spouses move into further education once abroad. In coastal Senegambia, therefore, trades such as guides, dancers or musicians have the double advantage of providing livelihoods in the present, and possible migration opportunities in the future (Neveu Kringelbach 2013). None of the longer relationships I have come across, however, could be reduced to migratory projects; rather, in some cases they have turned into marriages earlier than they would have if the couple had not been forced to worry about legal status. But as Froerer and Portisch (2012) remind us, formal education does not always deliver its promises. What role does marriage play in compromised educational trajectories?

\section{Marriage and compromised educational trajectories}

Whether or not marriage has positive educational outcomes is not only gendered, it is also contingent on age, class, legal status, place and of course individual ability. Thus by the time people are able to resume truncated educational trajectories, they may find themselves caught up in a web of obligations. West African migrants often find that expectations of remittances increase with the years as families expect success to bear a direct relation to the time spent away. In Senegal, remittances cut across all social classes since they are not only determined by economic need, but also by a reciprocal desire to maintain strong transnational connections (Riccio 2001). But marriage to a French citizen or resident creates a web of obligations of its own, and tensions arise when people must share their resources between family back home and a household in France. The passage to another life stage, then, means that marriage does not always have a positive effect on educational projects. 
For Nafissatou, a young Ivorian woman, marriage may have thus come too late. She had left secondary school in Côte d'Ivoire before completing the Baccalaureate and arrived in France in the early 2000s. Côte d'Ivoire was heading for civil war, and her mother was worried that her education may be compromised. Nafissatou came with a tourist visa, but found that this did not allow her to enrol in a state school. Some private schools were happy to turn a blind eye, but the family could not afford them. As Côte d'Ivoire descended deeper into crisis, Nafissatou's mother advised her against going back. Nafissatou remained undocumented for years, and coped by working as a nanny. She shared small flats with friends, moved often to avoid deportation, spent little on herself and sent money home to her mother, who was looking after her own ageing mother. Nafissatou eventually met a French man of her age, and they married the following year. Not only did they have to move a couple of times to find a town hall willing to marry them, they also endured administrative harassment for a year and a half to get a spouse visa for Nafissatou. By now, Nafissatou says it is too late for her to go back to school. She is still looking after children, and feels she cannot let her mother down by quitting work. She does not, either, wish to be entirely dependent on her husband's income since she feels that his family would then suspect her of marrying him 'for the papers and the money'. Moreover, having her own income enables her to send more money back home. She is considering doing a short training as a nursery worker, but only if this does not prevent her from working simultaneously.

In other cases, failed marriages compromise the legal status and educational opportunities of migrant spouses. For Amadou, a young Senegalese who came to France to study in the mid-2000s, marriage has been an unfortunate distraction. With a Baccalaureate from Senegal, Amadou hurried to France and ignored his mother's advice to complete a first degree at home. He failed his first-year exams and was offered a re-take, but in the meantime had become involved with a young French woman whose mother was Senegalese. He decided to move in with her and suspend his studies for a while. His student visa was not renewed, therefore, and marriage became an urgent matter. Although Amadou points out that he was in love, he confesses that the loss of his status hastened the process. The couple found a morally acceptable way of dealing with the urgency by doing a simple civil ceremony, and postponing the Muslim wedding until later. This way, Amadou was able to get a temporary spouse visa while they began the negotiations for the Muslim ceremony. Sadly, the relationship floundered soon after the religious ceremony, which was celebrated in Senegal. They eventually separated, but Amadou's wife went along with the pretence of a married life so that he could renew his visa. To put on the performance for him, he said, she demanded to be paid in cash.

Amadou's parents in Senegal are middle-class, university-educated and practising Muslims. Their priority is for him to get a degree before returning home, and they do not expect to receive remittances just yet. Amadou, for his part, cannot face the prospect of going home empty-handed, especially since his mother, whom I met in Senegal, had to borrow a significant sum of money for him to study abroad. Like Michelle, he works in restaurant kitchens, and is saving up to enrol in a private engineering course. From his perspective, marriage to a French citizen has undermined his education without giving him access to any rights. Amadou is only one of thousands of African students who go from aspirations of upward mobility to being trapped in a liminal space of immobility, where educational and personal aspirations are put on hold.

\section{Conclusion}

I have drawn on several generations of West African students in France to suggest that a focus on marriage sheds light on the relationship between migration, education and social mobility. Two main conclusions can be drawn from the material presented here.

Firstly, understanding the transformative effect of education abroad requires a focus on students as family members, which may include the roles of spouse and parent, rather than as autonomous individuals. This requires paying attention to educational trajectories as part of broader aspirations, a focus that is emerging in the literature on international student mobility. In the case of West African 
students in France, marriage to a citizen has long played an important role in educational trajectories by providing access to longer-term residency, citizenship, and an experiential knowledge of French everyday life.

Secondly, the ways in which transnational marriage shapes educational trajectories is contingent on a range of factors beyond individual abilities, particularly the political context and attitudes towards migrants, historical patterns of mobility, and the gender as well as class background of the migrants. In relation to the political context, I have attempted to show how the movement of West African students to France throughout the $20^{\text {th }}$ century has been encouraged by colonial, then post-colonial educational policies. In the more recent period, these students have become caught up in the tension between France's desire to maintain good relationships with its former colonies and rising anti-immigrant sentiments in France, particularly toward African Muslims. In this context, transnational marriage is likely to play an ever more important role in the fulfilment of educational projects. Where Senegal is concerned, this is in continuity with a history of French colonialism, which imposed a model of success linked to mastery of the French language, migration to acquire degrees, and incorporation into the creole coastal elites.

Gender also comes across here as a crucial element in the migration/education/marriage nexus: until the 1980s, it was mainly Senegalese men who benefited from degrees from French higher education institutions, and who married French women. In the past few decades, this gender imbalance has moved towards a gradual reversal with the increase in Senegalese girls' access to schooling, and to education abroad. Marriage between Senegalese women students and French men has also been fostered both by encounters in Senegal and by an increase in transnational marriage between Senegal and France, which in some cases involves French men of Senegalese origin.

Finally, class also figures as an important factor because most West Africans who have the opportunity to come to France to study are middle-class, often from families with a history of formal education over several generations. However, the cost of living in France and the inability of government studentships to cover living expenses, mean that West African families must often pool resources to send a student abroad. This, in turn, raises expectations that students will work their way through their studies and remit money back home. Failure to achieve this undermines the social status of both students and relatives, just as failure to acquire degrees is associated with downward mobility. In this context, marriage to a citizen may salvage compromised educational projects, but the passage to a new life stage may also undermine them. In any case, the evidence presented here makes a strong case for how educational trajectories both shape - and are shaped by - transnational marriages, and for the salience of colonial histories in international student mobility.

\section{Acknowledgments}

I am grateful to the Leverhulme Trust for funding the project on multinational families and new identities this study forms part of, within the Oxford Diaspora Programme (http://www.migration.ox.ac.uk/odp/).

\section{References cited}

Adi, Hakim. 1998. West Africans in Britain, 1900-1960: Nationalism, Pan-Africanism, and Communism. London: Lawrence \& Wishart.

Alba, Richard, and Victor Nee. 2005. Remaking the American Mainstream: Assimilation and Contemporary Immigration. Cambridge, MA: Harvard University Press.

ANSD. 2011. "Situation économique et sociale du Sénégal en 2010." In, edited by Agence Nationale de la Démographie et de la Statistique. Dakar. 
Baas, Michiel. 2006. "Students of migration: Indian overseas students and the question of permanent residency." Review of. People and Place 14 (1):9-24.

. 2010. Imagined Mobility: Migration and Transnationalism Among Indian Students in Australia. London: Anthem Press.

Beauchemin, Cris, Kim Caarls, and Valentina Mazzucato. 2013. "Senegalese migrants between here and there: an overview of family patterns." MAFE Working Papers.

Biao, Xiang, and Wei Shen. 2009. "International student migration and social stratification in China." Review of. International Journal of Educational Development 29 (513-522).

Bloch, Alexia 2011. "Intimate circuits: modernity, migration and marriage among post-Soviet women in Turkey." Review of. Global Networks 11 (4):502-21.

Brooks, Rachel, and Glyn Everett. 2008. "The prevalence of life planning: evidence from UK graduates." Review of. British Journal of Sociology Education 29:325-37.

Brooks, Rachel, and Joanna L. Waters. 2011. Student Mobilities: Migration and the Internationalization of Higher Education. Basingstoke: Palgrave Macmillan.

Bryceson, Deborah, and Ulla Vuorela. 2002. "The Transnational Family: New European Frontiers and Global Networks." In. Oxford: Berg.

Campus France. 2013. "Les Etudiants Internationaux. Chiffres clés France 2012-2013: Actualisation." In. Paris: Campus France.

Charsley, Katharine. 2012. "Transnational marriage." In Transnational Marriage: New Perspectives From Europe and Beyond, edited by Katharine Charsley, 3-22. London: Routledge.

. 2013. Transnational Pakistani Connections: Marrying 'Back Home’. London: Routledge.

Cole, Jennifer 2010. Sex and Salvation: Imagining the Future in Madagascar. Chicago: Chicago University Press.

Collet, Béate. 1993. "Couples mixtes en France, couples binationaux en Allemagne." Review of. Hommes \& Migrations 1167:15-9.

Constable, Nicole. 2005a. "Cross-Border Marriages: Gender and Mobility in Transnational Asia." In. Philadelphia: University of Pennsylvania Press.

. 2005b. "Introduction: cross-border marriages, gendered mobility, and global hypergamy." In Cross-Border Marriages: Gender and Mobility in Transnational Asia, edited by Nicole Constable, 1-16. Philadelphia: University of Pennsylvania Press.

Coulon, Alain, and Saeed Paivandi. 2003. "Les étudiants étrangers en France : l'état des savoirs. Rapport pour L'Observatoire de la Vie Étudiante." In. Paris: Université de Paris 8.

Dieng, Amady Aly. 2003. Les Premiers Pas de la Fédération des Etudiants d'Afrique Noire en France (1950-1955). De L'Union Française à Bandoung. Paris: L'Harmattan.

Diop, Abdoulaye-Bara. 1985. La Famille Wolof. Paris: Karthala.

Diouf, Mamadou. 1990. Le Kajoor au XIXe siècle: Pouvoir Ceddo et Conquête Coloniale. Paris: Karthala.

Ebron, Paulla. 1997. "Traffic in Men." In Gendered Encounters. Challenging Cultural boundaries and Social Hierarchies in Africa, edited by Maria Grosz-Ngate and Omari H. Kokole, 223-45. London \& New York: Routledge.

Fernandez, Nadine T. . 2013. "Moral Boundaries and National Borders: Cuban Marriage Migration to Denmark." Review of. Identities: Global Studies in Culture and Power 20 (3):270-87.

Findlay, Allan M, Russell King, Fiona M Smith, Alistair Geddes, and Ronald Skeldon. 2012. "World class? An investigation of globalisation, difference and international student mobility." Review of. Transactions of the Institute of British Geographers 37:118-31.

Fouquet, Thomas. 2007. "De la prostitution clandestine aux désirs de l'ailleurs : une "ethnographie de l'extraversion" à Dakar." Review of. Politique Africaine 3 (107):102-23.

Froerer, Peggy, and Anna Portisch. 2012. "Introduction to the Special Issue: Learning, Livelihoods, and Social Mobility." Review of. Anthropology and Education Quarterly 43 (4):332-43. 
Guèye, Abdoulaye. 2001. Les Intellectuels Africains en France. Paris: L'Harmattan.

. 2002. "Les intellectuels sénégalais en France." In Le Sénégal Contemporain, edited by Momar-Coumba Diop, 215-40. Paris: Karthala.

Guimont, Fabienne. 1997. Les Etudiants Africains en France (1950-1965). Paris: L'Harmattan.

Hajjat, Abdellali. 2012. Les Frontières de l'Identité Nationale. Paris: La Découverte.

INSEE. 2012. "Mariages mixtes et mariages étrangers par nationalité du conjoint." In, edited by Tableau 22. INSEE.

King, Russell, and Parvati Raghuram. 2013. "International student migration: mapping the field and new research agendas." Review of. Population, Space and Place 19:127-37.

Lambert, Michael C. 2002. Longing for Exile: Migration and the Making of a Translocal Community in Senegal, West Africa. Portmouth, NH: Heinemann.

Levinson, Bradley A., Douglas E. Foley, and Dorothy C. Holland. 1996. "The Cultural Production of the Educated Person: Critical Ethnographies of Schooling and Local Practice." In. Albany: State University of New York Press.

Linares, Olga. 1992. Power, Prayer and Production: the Jola of Casamance. Cambridge: Cambridge University Press.

Manchuelle, François. 1997. Willing Migrants: Soninke Labor Diasporas, 1848-1960. Athens: Ohio University Press.

Meillassoux, Claude. 1981. Maidens, Meal and Money: Capitalism and the Domestic Economy. Cambridge: Cambridge University Press.

Neveu Kringelbach, Hélène. 2013. Dance Circles: Movement, Morality and Self-Fashioning in Urban Senegal. Oxford: Berghahn.

Olwig, Karen F. 2007. Caribbean Journeys: An Ethnography of Migration and Home in Three Family Networks. Durham, N.C.: Duke University Press.

Olwig, Karen Fog, and Ninna Nyberg Sørensen. 2002. " Mobile livelihoods: making a living in the world." In Mobile livelihoods: Life and Livelihoods in a Globalizing World, edited by Karen Fog Olwig and Ninna Nyberg Sørensen, 1-19. London and New York: Routledge.

Paivandi, Saeed. 1998. "L'enquête sur les conditions de vie des étudiants à Paris 8. Rapport pour L’Observatoire de la Vie Étudiante." In. Paris: Université de Paris 8.

Raghuram, Parvati. 2013. "Theorising the spaces of student migration." Review of. Population, Space and Place 19:138-54.

Rao, Nitya. 2010. "Migration, education and socio-economic mobility." Review of. Compare: $A$ Journal of Comparative and International Education 40 (2):137-45.

Riccio, Bruno. 2001. "From "ethnic group" to "transnational community"? Senegalese migrants, ambivalent experiences, and multiple trajectories." Review of. Journal of Ethnic and Migration Studies 27 (4):583-99.

Rodriguez García, Dan 2006. "Mixed marriages and transnational families in the intercultural context: A case study of African Spanish couples in Catalonia." Review of. Journal of Ethnic and Migration Studies 32:403-33.

Rodríguez-García, Dan. 2012. "Considérations théoricométhodologiques autour de la mixité." Review of. Enfances, Familles, Générations 17:41-58.

Safi, Mirna. 2008. "Intermarriage and assimilation: Disparities in levels of exogamy among immigrants in France." Review of. Population 63 (2):239-68.

Salomon, Christine. 2009. "Antiquaires et businessmen de la Petite Côte du Sénégal. Le commerce des illusions amoureuses." Review of. Cahiers d'Etudes Africaines 1-2 (193-194):147-76.

Selly Baro, Sokhna. 2005. "Quête du savoir et stratégies d'insertion professionnelle : parcours d'émigration des étudiants et cadres sénégalais en France, aux Etats-Unis et au Québec. Unpublished $\mathrm{PhD}$ thesis." EHESS. 
Song, Miri. 2009. "Is intermarriage a good indicator of integration?" Review of. Journal of Ethnic and Migration Studies 35 (2):331-48.

Todd, Emmanuel. 1994. Le Destin des Immigrés. Assimilation et Ségrégation dans les Démocraties Occidentales. Paris: Seuil.

Tribalat, Michèle. 2009. "Mariages 'mixtes' et immigration en France." Espace, Populations, Sociétés.

UNESCO, Institut de Statistiques. 2013. "Profil éducation - Sénégal."

Vaillant, Janet. 2006. Vie de Léopold Sédar Senghor: Noir, Français et Africain. Paris: Karthala.

Valentin, Karen. 2012. "The role of education in mobile livelihoods: social and geographical routes of young Nepalese migrants in India." Review of. Anthropology \& Education Quarterly 43 (4):429-42.

Waters, Johanna L. 2006. "Geographies of cultural capital: education, international migration and family strategies between Hong Kong and Canada." Review of. Transactions of the Institute of British Geographers 31 (2):179-92.

White, Owen. 1999. Children of the French Empire: Miscegenation and Colonial Society in French West Africa, 1895-1960. Oxford: Oxford University Press.

Hélène Neveu Kringelbach is a project leader with the Oxford Diaspora Programme at the University of Oxford.

Address: African Studies Centre, 13 Bevington Road, Oxford OX2 6LH.

Email: helene.neveu@africa.ox.ac.uk. 